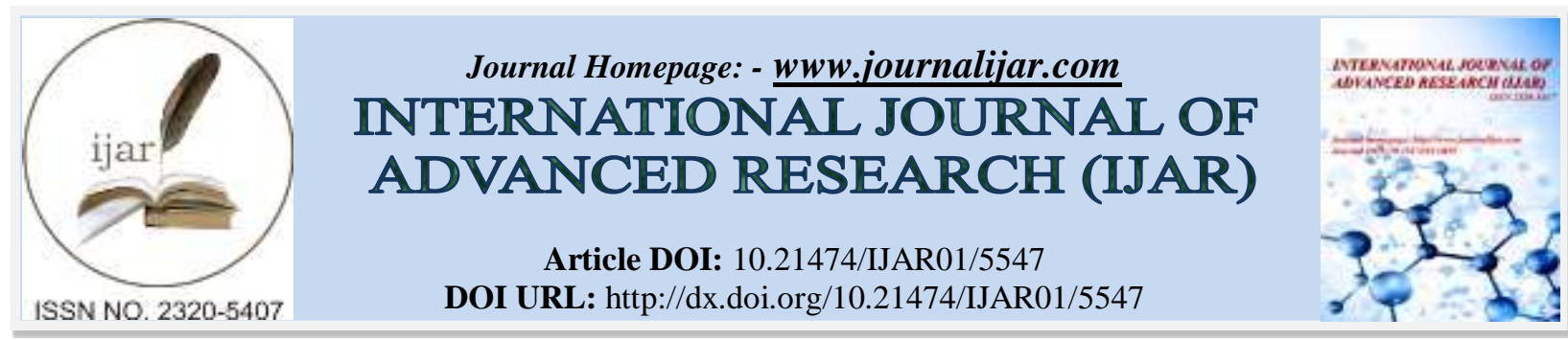

RESEARCH ARTICLE

\title{
STRATEGIES FOR ACCELERATING SECTORAL ECONOMIC GROWTH BASED ON LOCAL POTENTIALS OF REGENCIES IN MADURA.
}

Taufiq $^{1}$, Marseto ${ }^{1}$ and Rusdi H Nugroho ${ }^{2}$.

1. Lecturer in Faculty of Economic, Study Program of Development Economic, UPN"Veteran" East Java.

2. Lecturer of Business Administration, Faculty of Social and Political Sciences, UPN"Veteran" East Java.

\section{Manuscript Info}

Manuscript History

Received: 05 August 2017

Final Accepted: 07 September 2017

Published: October 2017

\begin{abstract}
The objective of research is to understand a model of local development planning based on sectoral aspect and local/regional excellence aspect. Method of analysis used in this research is SWOT. This analysis compares internal or external strategic factors and produces desired strategies to deal with each factor before conducing the scoring. Result of research indicates several findings. Economic structure in Sampang Regency is dominated by four (4) main sectors, such as: Sector of Agriculture, Animal Husbandry, Forestry and Fishery; Sector of Mining and Excavation; and Sector of Wholesale \& Retail, and Reparation. Economic stucture in Bangkalan Regency is dominated by four (4) leading sectors, including: Sector of Mining and Excavation; Sector of Agriculture, Animal Husbandry, Forestry, and Fishery; Sector of Mining and Excavation; Sector of Wholesale \& Retail, and Reparation; and Sector of Construction. Pamekasan Regency has its economic structure dominated by four (4) leading sectors, such as: Sector of Agriculture, Animal Husbandry, Forestry, and Fishery; Sector of Mining and Excavation; Sector of Wholesale \& Retail, and Reparation; Sector of Construction; and Sector of Government Administration, Defense, and Warranty. Four (4) sectors have been dominant in Sumenep Regency, including: Sector of Agriculture, Animal Husbandry, Forestry, and Fishery; Sector of Mining and Excavation; Sector of Wholesale \& Retail and Reparation; and Sector of Construction.
\end{abstract}

Copy Right, IJAR, 2017,. All rights reserved.

\section{Introduction:-}

Background:-

National development is a set of development efforts in any life aspects of the nation. It can be said that this development effort would be complex because it is not only involving intersectoral economical activities, but also encompassing relevant activities in regional context. Each development activity always involves regional (spatial) dimension. Development planning activity, therefore, must consider regional aspect comprehensively. For those interests, then model of local development planning based on sectoral aspect and local/regional excellence aspect.

Corresponding Author:- Taufiq.

Address:- Lecturer in Faculty of Economic, Study Program of Development Economic, UPN"Veteran" East Java. 


\section{Method Of Research:-}

One of approaches used as an instrument in selecting strategy is through SWOT analysis. This analysis is based on logics of maximizing strengths and opportunities, but in the other hand, minimizing weakness and threats. SWOT analysis attempts to compare external and internal factors. External factors include opportunities and threats, whereas internal factors involve strengths and weakness.

It can be said that SWOT analysis consists of four factors, including strengths, weakness, opportunities, and threats. SWOT analysis is very useful to analyze individual and environmental conditions, internal conditions of organization, and external environment. There is relationship across strengths, weakness, opportunities, and threats. SWOT analysis assigns strategy options in four quadrants:

Quadrant I. It is a fortunate situation. Company has opportunities and strengths to exploit existing opportunities. The expected strategy in this situation is to support aggresive growth policy.

Quadrant II. Despite the presence of threats, company still has internal strengths. The desired strategy is to use power to utilize long-term opportunities through diversification strategy (product/market).

Quadrant III. The company has very huge market opportunities, but in other hand, it also faces internal threats or weakness. The suggested strategy is focused on minimizing internal problem of company in order to capture better market share (turn around).

Quadrant IV. It is a situation without fortunes. The company must deal with threats and weakness. The recommended strategy is to perform a recovery step to escape from greater losses (defensive).

In SWOT analysis, internal and external strategic factors are compared to obtain strategy to deal with each factor, and after this, the scoring is conducted. Based on the result of analysis, the focus of recommended strategies is determined.

\section{Strategy Selection Model:-}

Pursuant to the model proposed by Boston Consulting Group (BCG), the options of suggested strategy are divided into four, respectively Star, Cash-Cow, Question-Mark, and Moldy. The selected strategy is made with two (2) criteria, respectively market growth and market share. The analysis in current research uses two (2) criteria, including sectoral economic growth and sectoral economic contribution.

Star Strategy is selected if the economic has high sectoral growth and also high sectoral contribution. Star sector needs great supports of capital investment to maximize growth potential. Star sector is considered as "improvident" in investment capital.

Cash-Cow Strategy comes into consideration if the economic has low sectoral growth but with high sectoral contribution. Cash-Cow sector does not need great supports of capital investment. Growth potential of Cash-Cow sector in the future is not greater than Star sector but Cash-Cow sector does not huge supports of new investment capital. This sector needs more policies of intensification.

Moldy Strategy is selected when the economic has low sectoral growth and low sectoral contribution. QuestionMark Strategy is used when sectoral growth of economic is high but with low sectoral contribution.

\section{Result And Discussion:-}

\section{Review on Economic in Sampang Regency}

Review on economic in Sampang Regency involves few macroeconomic indicators, such as: economic growth; the contribution of sectoral economic to PDRB of East Java Province; and the analysis on sectoral basis and sectoral non-basis potentials.

Added-value produced by Sampang Regency economic growth in 2014, based on 2010 constant price basis, is reaching for IDR 11,632.9 billions and IDR 11,874.5 billions in 2015. The economic growth of Sampang Regency equals to $0.99 \%$ of East Java economic in 2014, but it declines to $0.87 \%$ in 2015 . The reduction goes for $0.12 \%$. 
Table 1:- Economic Sectors with Above-Average Growth

\begin{tabular}{|l|l|l|l|}
\hline No & Economic Sector & Growth (\%) \\
\cline { 3 - 4 } & & 2014 & 2015 \\
\hline 1 & Transportation and Warehousing & 9.3 & 7.2 \\
\hline 2 & Information and Communication & 8.5 & 6.8 \\
\hline 3 & Accommodation and Consumption & 8.4 & 8.4 \\
\hline 4 & Wholesale \& Retail, and Reparation & 8.0 & 6.8 \\
\hline 5 & Financial and Insurance Services & 7.7 & 6.8 \\
\hline 6 & Education Service & 7.3 & 6.7 \\
\hline & PDRB Growth & 0.1 & 2.1 \\
\hline
\end{tabular}

Source : BPS data are processed.

Economic growth of Sampang Regency in 2014 and 2015 reaches for $0.1 \%$ and $2.1 \%$. Mean rate is $1.1 \%$, and it is lower than mean rate of East Java economic growth which attains 5.7\%. Most of these cconomic sectors, however, show a descending trend of growth. Sector of Transportation and Warehousing is growing at $9.3 \%$ in 2014 but declining to $7.2 \%$ in 2015 . The growth of Sector of Information and Communication has attained $8.5 \%$ in 2014 , but it decreases to $6.8 \%$ in 2015. The economic growth of Sector of Accommodation and Consumption is achieving $8.4 \%$ in 2014 and it remains same in 2015. Economic growth of Sector of Wholesale \& Retail, and Reparation goes at $8.0 \%$ in 2014 but then falls down to $6.8 \%$ in 2015. Sector of Financial and Insurance Services grows at $7.7 \%$ in 2014 but then declines to $6.8 \%$ in 2015 . Sector of Education Service is growing at $7.3 \%$ in 2014 but decreasing to $6.7 \%$ in 2015 .

\section{Economic Structure of Sampang Regency:-}

Sampang Regency economic structure is understood from the contribution of each economic sector to PDRB of Sampang Regency. The dominant sectors that contribute to Sampang Regency PDRB are set in the following table.

Table 2:- Sectoral Contribution in Sampang Regency

\begin{tabular}{|l|l|l|l|l|}
\hline \multirow{2}{*}{ No } & \multirow{2}{*}{ Economic Sector } & \multicolumn{3}{l|}{ Contribution (\%) } \\
\cline { 3 - 4 } & & 2013 & 2014 & 2015 \\
\hline 1 & Sector of Agriculture, Animal Husbandry, Forestry and Fishery & 29.6 & 30.6 & 31.4 \\
\hline & $\begin{array}{l}\text { Subsector of Agriculture, Animal Husbandry, Hunting and Farming } \\
\text { Service }\end{array}$ & 23.0 & 23.5 & 24.0 \\
\hline & Subsector of Fishery & 6.4 & 6.9 & 7.3 \\
\hline 2 & Sector of Mining and Excavation & 27.9 & 24.1 & 21.7 \\
\hline & Subsector of Mining for Oil, Gas and Native Heat & 23.0 & 19.1 & 16.7 \\
\hline 3 & Sector of Wholesale \& Retail, and Reparation & 14.6 & 15.7 & 16.4 \\
\hline & $\begin{array}{l}\text { Subsector of Wholesale \& Retail for Automobile/ Motorcycle } \\
\text { Wheels }\end{array}$ & 12.9 & 13.9 & 14.6 \\
\hline 4 & Sector of Information and Communication & 4.4 & 4.8 & 5.0 \\
\hline
\end{tabular}

Source : BPS data are processed.

Sampang Regency economic structure is dominated by four (4) main sectors, such as: Sector of Agriculture, Animal Husbandry, Forestry and Fishery; Sector of Mining and Excavation; Sector of Wholesale \& Retail, and Reparation; and Sector of Information and Communication. Contribution mean from Sector of Agriculture, Animal Husbandry, Forestry and Fishery to Sampang Regency PDRB in the last three years (from 2013 to 2015) is 30.5\%, followed by Sector of Mining and Excavation with 24.6\%, and Sector of Wholesale \& Retail, and Reparation with $15.6 \%$. Contribution mean from Sector of Information and Communication is the lowest. Some subsectors have dominant contribution, such as: Subsector of Agriculture, Animal Husbandry, Hunting, and Farming Service with contribution mean of 23.5\%; Subsector of Fishery with contribution mean of 6.9\%; Subsector of Mining for Oil, Gas and Native Heat with contribution mean of 19.6\%; and Subsector of Wholesale \& Retail for Automobile/ Motorcycle Wheels with contribution mean of $13.8 \%$.

In general, economic structure of Sampang Regency in the last three years, from 2013 to 2015, does not change a lot. The most dominant sector in the economic structure of this regency is Sector of Agriculture, Animal Husbandry, Forestry, and Fishery. 
Analysis on Economic Potentials:-

The analysis on Sampang Regency economic potentials is using parameters of Location Quotient and Klasen Typology. Location Quotient (LQ) of Sampang Regency

The analysis on leading sectors in Sampang Regency is utilizing Location Quotient (LQ). Result of analysis is presented in the following table.

Table 3:- Index of Location Quotient > 1 for Sampang Regency from 2013 - 2015

\begin{tabular}{|l|l|l|l|l|l|}
\hline No & Economic Sector/Subsector & 2013 & 2014 & 2015 & Mean \\
\hline 1 & $\begin{array}{l}\text { Sector of Agriculture, Animal Husbandry, Forestry and } \\
\text { Fishery }\end{array}$ & 2.35 & 2.48 & 2.60 & 2.47 \\
\hline & $\begin{array}{l}\text { Subsector of Agriculture, Animal Husbandry, Hunting and } \\
\text { Farming Service }\end{array}$ & 2.34 & 2.45 & 2.56 & 2.45 \\
\hline 2 & Subsector of Fishery & 2.84 & 3.04 & 3.20 & 3.02 \\
\hline & Sector of Mining and Excavation & 5.64 & 5.01 & 4.40 & 5.01 \\
\hline 3 & Subsector of Mining for Oil, Gas and Native Heat & 6.80 & 5.87 & 4.92 & 5.86 \\
\hline
\end{tabular}

Source : BPS data are processed.

In the last three years from 2013 to 2015, there are three (3) sectors and four (4) subsectors in the category of basis sector. LQ more than 1 (one) is attained by three sectors, such as: Sector of Agriculture, Animal Husbandry, Forestry and Fishery; Sector of Mining and Excavation; and Sector of Government Administration, Defense, and Warranty. Subsectors in basis sector category are: Subsector of Agriculture, Animal Husbandry, Hunting and Farming Service; Subsector of Fishery; Subsector of Mining for Oil, Gas and Native Heat; and Subsector of Mining and Excavation for Other Materials.

Klasen Typology Analysis:-

Klasen Typology Analysis for Sampang Regency in 2014 and 2015 is displayed in the following table.

Table 4:- Klasen Typology Analysis for Sampang Regency in 2014 - 2015

\begin{tabular}{|l|l|l|}
\hline \multirow{2}{*}{ Indicator } & Indicator Rate \\
\cline { 2 - 3 } & 2014 & 2015 \\
\hline PDRB Growth Rate for Regency/City & 0.1 & 2.1 \\
\hline PDRB Growth Rate for Province & 5.8 & 5.2 \\
\hline Income per Capita in Regency & 12,564 & 12,676 \\
\hline Income per Capita in Regency & 32,704 & 34,273 \\
\hline Conclusion of Local Typology & Relatively Undeveloped Area & Relatively Undeveloped Area \\
\hline
\end{tabular}

Source : BPS data are processed.

In the last two years from 2014 to 2015, based on criteria of Klasen Typology Analysis, Sampang Regency tends to be relatively undeveloped area. Economic growth mean of this regency is lower than that of East Java Province, and so is the mean of its income per capita. Sampang Regency economic growth is $0.1 \%$ in 2014 and $2.1 \%$ in 2015 whereas economic growth of East Java Province is 5.8\% in 2014 and 5.2\% in 2015. Sampang Regency income per capita has attained at IDR 12,564 millions in 2014 and IDR 12,676 millions in 2015, while income per capita of East Java Province is IDR 32.704 millions in 2014 and IDR 34.273 millions in 2015.

\section{Strategy Selection Model:-}

After adopting model suggested by Boston Consulting Group (BCG), some strategies are then selected to accelerate economic growth of Sampang Regency. The selected strategies based on economic sectors and subsectors are explained as following. 
Table 5:- Strategy Selection Model Based on BCG

\begin{tabular}{|l|l|l|l|l|}
\hline No & Sector / Subsector & $\begin{array}{l}\text { Sectoral Growth } \\
(\%)\end{array}$ & $\begin{array}{l}\text { Sectoral } \\
\text { Contribution (\%) }\end{array}$ & Strategy Selection \\
\hline 1 & $\begin{array}{l}\text { Sector of Agriculture, Animal Husbandry, } \\
\text { Forestry and Fishery }\end{array}$ & 4.15 & 30.53 & Star \\
\hline & $\begin{array}{l}\text { Subsector of Agriculture, Animal } \\
\text { Husbandry, Hunting and Farming Service }\end{array}$ & 3.10 & 23.50 & Star \\
\hline 2 & $\begin{array}{l}\text { Subsector of Fishery } \\
\text { Sector of Mining and Excavation }\end{array}$ & 7.90 & 6.86 & Star \\
\hline $\begin{array}{l}\text { Subsector of Mining for Oil, Gas and } \\
\text { Native Heat }\end{array}$ & $\begin{array}{l}\text { Subsector of Mining and Excavation for } \\
\text { Other Materials }\end{array}$ & 1.85 & 24.56 & Cash-Cow \\
\hline 3 & $\begin{array}{l}\text { Sector of Government Administration, } \\
\text { Defense, and Warranty }\end{array}$ & 4.9 & 4.4 & Question-Mark \\
\hline & Mean & & & Question-Mark \\
\hline
\end{tabular}

Of three basis sectors in Sampang Regency, it seems that Sector of Agriculture, Animal Husbandry, Forestry and Fishery is considered as Star Sector. This sector implements strategy of collecting great supports from new investment fund, and therefore, this sector is considered as "improvident" in capital necessity. Despite such improvidence, this Star Sector is the expected sector in Sampang Regency for the future. Two subsectors in Sampang Regency constitute star category, respectively Subsector of Agriculture, Animal Husbandry, Hunting and Farming Service and Subsector of Fishery.

Sector of Mining and Excavation is a sector with characteristic of Cash-Cow. This sector is not adequately promising to produce good expectancy in the future. Despite such weakness, this sector is a relatively good source of growth in Sampang Regency for now. Thus, Sector of Mining and Excavation would not need large amount of new investment fund. Moreover, in Sampang Regency, there is one subsector in cash-cow category, and this is Subsector of Mining for Oil, Gas and Native Heat.

Sector of Government Administration, Defense, and Warranty has question-mark characteristic. This sector has two opportunities, such as emphasizing on growth and facilitating the sector into further development by giving it an injection of capital investment. Selecting policy option may need deep review. In Sampang Regency, one subsector is classified into question-mark category, and this is Subsector of Mining and Excavation for Other Materials.

\section{Review on Economic in Bangkalan Regency:-}

The economic of Bangkalan Regency has been reviewed. Macroeconomic indicators determining this economic would involve economic growth; the contribution of sectoral economic to PDRB of East Java Province; and the analysis on sectoral basis and sectoral non-basis potentials.

Added-value derived from Bangkalan Regency economic growth, based on 2010 constant price basis, has reached for IDR 17,369.8 billions in 2014 and IDR 16,907.1 billions in 2015. These numbers equal to 1.58\% of East Java economic in 2014 and to $1.12 \%$ in 2015 , which signifies a fact of reduction by $0.46 \%$.

Table 6:- Economic Sectors with Above-Average Growth

\begin{tabular}{|l|l|l|l|}
\hline No & Economic Sector & Growth (\%) & 2015 \\
\cline { 3 - 4 } & & 2014 & 8.2 \\
\hline 1 & Accommodation and Consumption & 8.2 & 7.2 \\
\hline 2 & Information and Communication & 7.0 & 4.4 \\
\hline 3 & Wholesale \& Retail, and Reparation & 7.1 & 7.0 \\
\hline 4 & Health and Social Education Services & 5.2 & 4.2 \\
\hline 5 & Transportation and Warehousing & 5.2 & 4.8 \\
\hline 6 & Processing Industry & 4.8 & -2.7 \\
\hline & PDRB Growth & 7.2 & \\
\hline
\end{tabular}

Source: BPS data are processed. 
Bangkalan Regency economic growth in both 2014 and 2015 is attaining for $7.2 \%$ and $-2.7 \%$ with mean rate of $2.25 \%$. This mean rate seems low compared to that of East Java which stands for 5.7\%. The economic sectors of Bangkalan Regency have a more promising trend of growth. Sector of Accommodation and Consumption grows from $8.2 \%$ in 2014 and it remains same in 2015. Sector of Information and Communication has grown from $7.0 \%$ in 2014 to $7.2 \%$ in 2015. However, economic growth of Sector of Wholesale \& Retail, and Reparation declines from $7.1 \%$ in 2014 to $4.2 \%$ in 2015. Economic growth in Sector of Processing Industry remains same in both years which stands for $4.8 \%$.

\section{Economic Structure of Bangkalan Regency:-}

The economic structure of Bangkalan Regency is measured from the contribution of economic sectors to Bangkalan Regency PDRB. The following table is outlining some sectors with great contribution to PDRB of Bangkalan Regency.

Table 7:- Sectoral Contribution in Bangkalan Regency

\begin{tabular}{|l|l|l|l|l|}
\hline \multirow{2}{*}{ No } & Economic Sector & \multicolumn{3}{l|}{ Contribution (\%) } \\
\cline { 2 - 4 } & & 2013 & 2014 & 2015 \\
\hline 1 & Sector of Mining and Excavation & 38.6 & 39.8 & 35.0 \\
\hline & Subsector of Mining for Oil, Gas and Native Heat & 37.3 & 38.6 & 33.7 \\
\hline 2 & Sector of Agriculture, Animal Husbandry, Forestry and Fishery & 20.4 & 19.6 & 20.9 \\
\hline & $\begin{array}{l}\text { Subsector of Agriculture, Animal Husbandry, Hunting and } \\
\text { Farming Service }\end{array}$ & 13.8 & 13.2 & 14.1 \\
\hline & Subsector of Fishery & 6.5 & 6.3 & 6.7 \\
\hline & Sector of Wholesale \& Retail, and Reparation & 12.3 & 12.3 & 13.2 \\
\hline 4 & $\begin{array}{l}\text { Subsector of Wholesale \& Retail for Automobile/ Motorcycle } \\
\text { Wheels }\end{array}$ & 9.4 & 9.4 & 10.0 \\
\hline
\end{tabular}

Source : BPS data are processed.

Economic structure of Bangkalan Regency is characterized by four (4) dominant sectors, including Sector of Mining and Excavation; Sector of Agriculture, Animal Husbandry, Forestry and Fishery; Sector of Wholesale \& Retail, and Reparation; and Sector of Construction. Mean rate of contribution from Sector of Mining and Excavation to Bangkalan Regency PDRB in the last three years from 2013 to 2015 is 37.8\%, as the highest, followed by Sector of Agriculture, Animal Husbandry, Forestry and Fishery with 20.3\% and Sector of Wholesale \& Retail, and Reparation with $12.6 \%$. Sector of Construction is the lowest and the rate is negligible. Subsectors with dominant contribution can be set in order, such as: Subsector of Mining for Oil, Gas and Native Heat with contribution of 36.53\%; Subsector of Agriculture, Animal Husbandry, Hunting, and Farming Service with contribution of 13.7\%; and Subsector of Fishery with contribution of $6.5 \%$.

Bangkalan Regency economic structure in the last three years from 2013 to 2015 does not show a great change. The most dominant sector in the economic structure of Bangkalan Regency is Sector of Mining and Excavation.

\section{Analysis on Economic Potentials:-}

Economic potentials of Bangkalan Regency have been analyzed using parameters of Location Quotient and Klasen Typology.

\section{Location Quotient (LQ) of Bangkalan Regency}

The leading sectors in Bangkalan Regency are analyzed using Location Quotient (LQ). The result is shown in the following table.

Table 8:- Index of Location Quotient > 1 for Bangkalan Regency from 2013 - 2015

\begin{tabular}{|l|l|l|l|l|l|}
\hline No & Economic Sector/Subsector & 2013 & 2014 & 2015 & Mean \\
\hline 1 & $\begin{array}{l}\text { Sector of Agriculture, Animal Husbandry, Forestry and } \\
\text { Fishery }\end{array}$ & 1.62 & 1.59 & 1.73 & 1.64 \\
\hline $\begin{array}{l}\text { Subsector of Agriculture, Animal Husbandry, Hunting and } \\
\text { Farming Service }\end{array}$ & 1.40 & 1.38 & 1.51 & 1.43 \\
\hline & Subsector of Fishery & 2.89 & 2.77 & 2.94 & 2.86 \\
\hline
\end{tabular}




\begin{tabular}{|l|l|l|l|l|l|}
\hline 2 & Sector of Mining and Excavation & 7.79 & 8.25 & 7.09 & 7.71 \\
\hline & Subsector of Mining for Oil, Gas and Native Heat & 11.04 & 11.83 & 9.91 & 10.92 \\
\hline 3 & $\begin{array}{l}\text { Sector of Government Administration, Defense, and } \\
\text { Warranty }\end{array}$ & 1.87 & 1.86 & 2.00 & 1.91 \\
\hline 4 & Sector of Education Service & 1.19 & 1.15 & 1.24 & 1.19 \\
\hline
\end{tabular}

Source: BPS data are processed.

Within Bangkalan Regency, the last three years from 2013 to 2015 have indicated four (4) sectors and three (3) subsectors in the category of basis sector. Sectors with LQ more than 1 (one) include: Sector of Agriculture, Animal Husbandry, Forestry and Fishery; Sector of Mining and Excavation; Sector of Government Administration, Defense, and Warranty; and Sector of Education Service. Subsectors in basis sector category include: Subsector of Agriculture, Animal Husbandry, Hunting and Farming Service; Subsector of Fishery; and Subsector of Mining for Oil, Gas and Native Heat.

Klasen Typology Analysis:-

Klasen Typology Analysis for Bangkalan Regency in 2014 and 2015 is described in the following table.

Table 9:- Klasen Typology Analysis for Bangkalan Regency in 2014-2015

\begin{tabular}{|l|l|l|}
\hline \multirow{2}{*}{ Indikator } & Indicator Rate \\
\cline { 2 - 3 } & 2014 & 2015 \\
\hline PDRB Growth Rate for Regency/City & 7.2 & -2.7 \\
\hline PDRB Growth Rate for Province & 5.8 & 5.2 \\
\hline Income per Capita in Regency & 18,365 & 17,717 \\
\hline Income per Capita in Regency & 32,704 & 34,273 \\
\hline Conclusion of Local Typology & Fast Developing Area & Relatively Undeveloped Area \\
\hline
\end{tabular}

Source : BPS data are processed.

Based on data in the last two years from 2014 to 2015, and also taking into account the criteria of Klasen Typology Analysis, it can be said that Bangkalan Regency is relatively undeveloped area. It is said so because both mean rates of economic growth and income per capita of Bangkalan Regency is lower than East Java. Economic growth of Bangkalan Regency is $7.2 \%$ in 2014 and $-2.7 \%$ in 2015 whereas that of East Java Province is 5.8\% in 2014 and 5.2\% in 2015. Income per capita of Bangkalan Regency attains IDR 18,365 millions in 2014 and IDR 17,717 millions in 2015, while income per capita of East Java Province stands at IDR 32,704 millions in 2014 and IDR 34,273 millions in 2015 .

\section{Strategy Selection Model:-}

Model suggested by Boston Consulting Group (BCG) is adopted. By this model, the selection of strategies for accelerating economic growth of Bangkalan Regency based on economic sectors and subsectors would be described as following.

Table 10:- Strategy Selection Model Based on BCG

\begin{tabular}{|c|c|c|c|c|}
\hline No & Sector/Subsector & $\begin{array}{l}\text { Sectoral Growth } \\
(\%)\end{array}$ & $\begin{array}{l}\text { Sectoral } \\
\text { Contribution } \\
(\%)\end{array}$ & Strategy Selection \\
\hline \multirow[t]{3}{*}{1} & $\begin{array}{l}\text { Sector of Agriculture, Animal Husbandry, } \\
\text { Forestry and Fishery }\end{array}$ & 3.4 & 20.3 & Star \\
\hline & $\begin{array}{l}\text { Subsector of Agriculture, Animal Husbandry, } \\
\text { Hunting and Farming Service }\end{array}$ & 3.3 & 13.7 & Star \\
\hline & Subsector of Fishery & 3.5 & 6.5 & Star \\
\hline \multirow[t]{2}{*}{2} & Sector of Mining and Excavation & -1.95 & 37.8 & Cash-Cow \\
\hline & $\begin{array}{l}\text { Subsector of Mining for Oil, Gas and Native } \\
\text { Heat }\end{array}$ & -2.05 & 36.5 & Cash-Cow \\
\hline 3 & $\begin{array}{l}\text { Sector of Government Administration, } \\
\text { Defense, and Warranty }\end{array}$ & 2.85 & 4.4 & Question-Mark \\
\hline 4 & Sector of Education Service & 5.1 & 3.1 & Question-Mark \\
\hline
\end{tabular}




\section{Mean}

In Bangkalan Regency, Star Sector post is occupied by Sector of Agriculture, Animal Husbandry, Forestry and Fishery. The selected strategy in this sector is by compiling huge supports from new investment fund, and it can be said that this sector becomes "improvident" in capital necessity. Although it has such improvidence, this Star Sector is a sector with the expected future in Bangkalan Regency. Star category in Bangkalan Regency includes two subsectors, respectively Subsector of Agriculture, Animal Husbandry, Hunting, and Farming Service; and Subsector of Fishery.

The post of Cash-Cow Sector is filled by Sector of Mining and Excavation. This sector does not seem adequate to produce the expected future but it is a relatively good source of Bangkalan Regency growth in current days. Sector of Mining and Excavation also does not require large amount of new investment fund. In Bangkalan Regency, only one subsector has a cash-cow characteristic, and this is Subsector of Mining for Oil, Gas and Native Heat.

Question-Mark characteristic is shown by Sector of Government Administration, Defense, and Warranty. This sector has two opportunities, respectively emphasizing on growth and facilitating the sector into further development by giving an injection of capital investment. Deep review is needed before selecting policy option.

\section{Review on Economic in Pamekasan Regency:-}

Review on Pamekasan Regency economic concerns with macroeconomic indicators, such as: economic growth; the contribution of sectoral economic to PDRB of East Java Province; and the analysis on sectoral basis and sectoral non-basis potentials.

Added-value given by Pamekasan Regency economic growth, based on 2010 constant price basis, is attaining IDR 8,846.2 billions in 2014 and IDR 9,317.2 billions in 2015. If compared to East Java Province, economic growth of Pamekasan Regency is equivalent to $0.71 \%$ in 2014 and $0.73 \%$ in 2015 . It indicates an increase by $0.02 \%$.

Table 11:- Economic Sectors with Above-Average Growth

\begin{tabular}{|l|l|l|l|}
\hline No & Economic Sector & Growth (\%) \\
\cline { 3 - 4 } & & 2014 & 2015 \\
\hline 1 & Transportation and Warehousing & 10.3 & 7.6 \\
\hline 2 & Enterprise Service & 10.0 & 8.0 \\
\hline 3 & Accommodation and Consumption & 8.4 & 8.1 \\
\hline 4 & Processing Industry & 7.8 & 7.8 \\
\hline 5 & Information and Communication & 7.6 & 7.5 \\
\hline 6 & Real Estate & 6.9 & 6.8 \\
\hline & PDRB Growth & 5.6 & \\
\hline
\end{tabular}

Source: BPS data are processed.

Economic growth of Pamekasan Regency in 2014 and 2015 has reached 5.6\% and 5.3\%. Mean rate of this growth is $1.1 \%$, and it must be lower than mean rate of East Java economic growth which stands for 5.7\%. Growth trend of economic sectors is mostly declining. Sector of Transportation and Warehousing is growing at $10.3 \%$ in 2014 but decreasing to $7.6 \%$ in 2015. The growth of Sector of Enterprise Service has attained $10.0 \%$ in 2014 but then declined to $8.0 \%$ in 2015. Economic growth of Sector of Accommodation and Consumption is achieving $8.4 \%$ in 2014 and dropping to $8.1 \%$ in 2015. Economic growth of Sector of Wholesale \& Retail, and Reparation goes at $8.0 \%$ in 2014 but then falls down to $6.8 \%$ in 2015. Sector of Processing Industry grows at $7.8 \%$ in 2014 and it remains same in 2015. Sector of Information and Communication is growing at $6.9 \%$ in 2014 but decreasing little bit to $6.8 \%$ in 2015. Sector of Real Estate has economic growth of $6.9 \%$ in 2014 and it also goes down for little to $6.8 \%$ in 2015 .

\section{Economic Structure of Pamekasan Regency:-}

Pamekasan Regency economic structure can be understood from the contribution of each economic sector to Pamekasan Regency PDRB. The dominant sectors and their contribution to Pamekasan Regency PDRB are described in the following table. 
Table 12:- Sectoral Contribution in Pamekasan Regency

\begin{tabular}{|c|c|c|c|c|}
\hline \multirow[t]{2}{*}{ No } & \multirow[t]{2}{*}{ Economic Sector } & \multicolumn{3}{|c|}{ Contribution (\%) } \\
\hline & & 2013 & 2014 & 2015 \\
\hline \multirow[t]{3}{*}{1} & Sector of Agriculture, Animal Husbandry, Forestry and Fishery & 33.3 & 33.0 & 32.5 \\
\hline & $\begin{array}{l}\text { Subsector of Agriculture, Animal Husbandry, Hunting and Farming } \\
\text { Service }\end{array}$ & 24.3 & 23.8 & 23.2 \\
\hline & Subsector of Fishery & 8.9 & 9.0 & 9.2 \\
\hline \multirow[t]{3}{*}{2} & Sector of Wholesale \& Retail, and Reparation & 19.9 & 20.2 & 20.6 \\
\hline & $\begin{array}{l}\text { Subsector of Wholesale \& Retail for Automobile/ Motorcycle } \\
\text { Wheels }\end{array}$ & 16.2 & 16.5 & 17.0 \\
\hline & Subsector of Trading for Automobile/Motorcycle and Reparation & 3.7 & 3.7 & 3.7 \\
\hline 3 & Sector of Construction & 10.2 & 10.3 & 10.2 \\
\hline 4 & Sector of Government Administration, Defense, and Warranty & 7.3 & 7.0 & 6.9 \\
\hline
\end{tabular}

Source: BPS data are processed.

Pamekasan Regency economic structure is dominated by four (4) main sectors, such as: Sector of Agriculture, Animal Husbandry, Forestry and Fishery; Sector of Wholesale \& Retail, and Reparation; Sector of Construction; and Sector of Government Administration, Defense, and Warranty. The highest contribution mean to Pamekasan Regency PDRB in the last three years (from 2013 to 2015) is given by from Sector of Agriculture, Animal Husbandry, Forestry and Fishery with 32.9\%, followed by Sector of Wholesale \& Retail, and Reparation with 20.2\%, Sector of Construction with $10.2 \%$, and Sector of Government Administration, Defense, and Warranty with $7.06 \%$. Some subsectors already have dominant contribution, such as: Subsector of Agriculture, Animal Husbandry, Hunting, and Farming Service with contribution of 23.7\%; Subsector of Fishery with contribution of 9.03\%; Subsector of Wholesale \& Retail for Automobile/ Motorcycle Wheels with contribution of 16.5\%; and Subsector of Trading for Automobile/Motorcycle and Reparation with contribution of $3.7 \%$.

In general, economic structure of Pamekasan Regency in the last three years, from 2013 to 2015, is not greatly changing. The most dominant sector in this regency is Sector of Agriculture, Animal Husbandry, Forestry, and Fishery.

\section{Analysis on Economic Potentials:-}

The analysis on Pamekasan Regency economic potentials is using parameters of Location Quotient and Klasen Typology.

Location Quotient (LQ) of Pamekasan Regency:-

The analysis on leading sectors in Pamekasan Regency is utilizing Location Quotient (LQ). Result of analysis is indicated as following.

Table 3:- Index of Location Quotient > 1 for Pamekasan Regency from 2013 - 2015

\begin{tabular}{|l|l|l|l|l|l|}
\hline No & Economic Sector/Subsector & 2013 & 2014 & 2015 & Mean \\
\hline 1 & Sector of Government Administration, Defense, and Warranty & 3.04 & 3.06 & 3.01 & 3.03 \\
\hline 2 & $\begin{array}{l}\text { Sector of Agriculture, Animal Husbandry, Forestry and } \\
\text { Fishery }\end{array}$ & 2.64 & 2.67 & 2.68 & 2.66 \\
\hline $\begin{array}{l}\text { Subsector of Agriculture, Animal Husbandry, Hunting and } \\
\text { Farming Service }\end{array}$ & 2.47 & 2.48 & 2.48 & 2.47 \\
\hline 3 & Subsector of Fishery & 3.94 & 3.97 & 4.01 & 3.97 \\
\hline 4 & Sector of Education Service & 1.68 & 1.66 & 1.65 & 1.66 \\
\hline
\end{tabular}

Source : BPS data are processed.

In the last three years from 2013 to 2015, there are four (4) sectors and two (2) subsectors in the category of basis sector. All related sectors including Sector of Government Administration, Defense, and Warranty; Sector of Agriculture, Animal Husbandry, Forestry and Fishery; Sector of Education Service; and Sector of Health and Social Education Services, have LQ more than 1 (one). Subsectors in basis sector category include: Subsector of Agriculture, Animal Husbandry, Hunting and Farming Service; and Subsector of Fishery. 


\section{Klasen Typology Analysis:-}

Klasen Typology Analysis for Pamekasan Regency in 2014 and 2015 is displayed in the following table.

Table 14:- Klasen Typology Analysis for Pamekasan Regency in 2014 - 2015

\begin{tabular}{|l|l|l|}
\hline \multirow{2}{*}{ Indicator } & Indicator Rate \\
\cline { 2 - 3 } & 2014 & 2015 \\
\hline PDRB Growth Rate for Regency/City & 5.6 & 5.3 \\
\hline PDRB Growth Rate for Province & 5.8 & 5.2 \\
\hline Income per Capita in Regency & 10,579 & 11,022 \\
\hline Income per Capita in Regency & 32,704 & 34,273 \\
\hline Conclusion of Local Typology & Relatively Undeveloped Area & Fast Developing Area \\
\hline
\end{tabular}

Source : BPS data are processed.

In the last two years from 2014 to 2015, based on criteria of Klasen Typology Analysis, Pamekasan Regency is considered as relatively undeveloped area in 2014 but it successfully becomes fast developing area in 2015. Pamekasan Regency economic growth is 5.6\% in 2014 and 5.3\% in 2015 whereas economic growth of East Java Province is 5.8\% in 2014 and 5.2\% in 2015. Meanwhile, Pamekasan Regency income per capita has attained at IDR 32,704 millions in 2014 and IDR 34,273 millions in 2015, while income per capita of East Java Province is IDR 32.704 millions in 2014 and IDR 34.273 millions in 2015.

\section{Strategy Selection Model:-}

After adopting model suggested by Boston Consulting Group (BCG), some strategies are then selected to accelerate economic growth of Pamekasan Regency. Strategies selected based on economic sectors and subsectors are described in the following.

Table 15:- Strategy Selection Model Based on BCG

\begin{tabular}{|l|l|l|l|l|}
\hline No & Sector / Subsector & $\begin{array}{l}\text { Sectoral Growth } \\
(\%)\end{array}$ & $\begin{array}{l}\text { Sectoral } \\
\text { Contribution (\%) }\end{array}$ & Strategy Selection \\
\hline 1 & $\begin{array}{l}\text { Sector of Government Administration, } \\
\text { Defense, and Warranty }\end{array}$ & 2.30 & 7.06 & Cash-Cow \\
\hline 2 & $\begin{array}{l}\text { Sector of Agriculture, Animal Husbandry, } \\
\text { Forestry and Fishery }\end{array}$ & 4.25 & 32.9 & Cash-Cow \\
\hline & $\begin{array}{l}\text { Subsector of Agriculture, Animal } \\
\text { Husbandry, Hunting and Farming Service }\end{array}$ & 3.10 & 23.7 & Cash-Cow \\
\hline 3 & Subsector of Fishery & 7.20 & 9.03 & Star \\
\hline 4 & Sector of Education Service & 5.30 & 4.4 & Moldy \\
\hline & $\begin{array}{l}\text { Sector of Health and Social Education } \\
\text { Services }\end{array}$ & 4.70 & 0.7 & Moldy \\
\hline & Mean & & & \\
\hline
\end{tabular}

Of basis category existing in Pamekasan Regency, it seems that only Subsector of Fishery is given a status of Star. This subsector implements strategy of enlisting supports by collecting new investment fund, and therefore, this subsector is considered as "improvident" in capital necessity. Despite such unfavorable characteristic, it is the expected business in Pamekasan Regency in the future.

Both Sector of Education Service and Sector of Health and Social Education Services are assigned into moldy sectors. Both shall not be adequately promising to produce good expectancy either at now or in the future. They are "negligible" and thus, do not need great amount of investment fund. They are also incapable of giving maximum result either in present days or in the future.

Two sectors have characteristic of cash-cow, respectively Sector of Government Administration, Defense, and Warranty, and Sector of Agriculture, Animal Husbandry, Forestry and Fishery. Both sectors definitely find difficulty in meeting expectation in the future, but they grow well in nowadays in Pamekasan Regency. As a result, both sectors do not need large amount of new investment fund. Moreover, in Pamekasan Regency, there is one subsector in cash-cow category, and this is Subsector of Agriculture, Animal Husbandry, Hunting and Farming Service. 


\section{Review on Economic in Sumenep Regency:-}

The economic of Sumenep Regency has been subjeted to a review. Macroeconomic indicators of this economic involve economic growth; the contribution of sectoral economic to PDRB of East Java Province; and the analysis on sectoral basis and sectoral non-basis potentials.

Added-value derived from Sumenep Regency economic growth, based on 2010 constant price basis, has attained as IDR 21,476.8 billions in 2014 and IDR 21,750.5 billions in 2015. These numbers are equivalent with $1.56 \%$ of East Java economic in 2014 and to $1.59 \%$ in 2015 , and these signify an increase of $0.03 \%$.

Table 16:- Economic Sectors with Above-Average Growth

\begin{tabular}{|l|l|l|l|}
\hline No & Economic Sector & Growth $(\%)$ \\
\cline { 3 - 4 } & & 2014 & 2015 \\
\hline 1 & Information and Communication & 12.5 & 7.6 \\
\hline 2 & Accommodation and Consumption & 9.8 & 9.6 \\
\hline 3 & Transportation and Warehousing & 9.6 & 9.1 \\
\hline 4 & Financial and Insurance Services & 9.3 & 8.4 \\
\hline 5 & Health and Social Education Services & 8.7 & 8.9 \\
\hline 6 & Education Service & 8.7 & 8.5 \\
\hline & PDRB Growth & 6.2 & 1.3 \\
\hline
\end{tabular}

Source : BPS data are processed.

Sumenep Regency economic growth in both 2014 and 2015 is attaining for $6.2 \%$ and $1.3 \%$ with mean rate of 3.75\%. This mean rate seems lower if compared to that of East Java which stands for 5.7\%. Unfortunately, economic sectors in Sumenep Regency have a trend of decline. The growth of Sector of Information and Communication declines from 12.5\% in 2014 to 7.6\% in 2015. Sector of Accommodation and Consumption has its growth declining from $9.8 \%$ in 2014 to $9.6 \%$ in 2015. Economic growth of Sector of Transportation and Warehousing decreases from 9.6\% in 2014 and 9.1\% in 2015. Sector of Financial and Insurance Services grows at 9.3\% in 2014 but it goes down at $8.4 \%$ in 2015. Sector of Health and Social Education Services indicates an increasing growth from $8.7 \%$ in 2014 and $8.9 \%$ in 2015. Sector of Education Service experiences a decrease from $8.7 \%$ in 2014 and $8.5 \%$ in 2015.

\section{Economic Structure of Sumenep Regency:-}

The economic structure of Sumenep Regency has been measured from the contribution of economic sectors to Sumenep Regency PDRB. The following table displays some sectors with great contribution to PDRB of Sumenep Regency.

Table 17:- Sectoral Contribution in Sumenep Regency

\begin{tabular}{|l|l|l|l|l|}
\hline \multirow{2}{*}{ No } & \multirow{2}{*}{ Economic Sector } & \multicolumn{3}{l|}{ Contribution (\%) } \\
\cline { 3 - 4 } & & 2013 & 2014 & 2015 \\
\hline 1 & Sector of Agriculture, Animal Husbandry, Forestry and Fishery & 33.0 & 32.1 & 33.0 \\
\hline & $\begin{array}{l}\text { Subsector of Agriculture, Animal Husbandry, Hunting and } \\
\text { Farming Service }\end{array}$ & 20.0 & 19.4 & 19.6 \\
\hline & Subsector of Fishery & 12.8 & 12.4 & 13.1 \\
\hline 2 & Sector of Mining and Excavation & 31.5 & 32.0 & 29.3 \\
\hline 3 & Subsector of Mining for Oil, Gas and Native Heat & 29.0 & 29.7 & 26.9 \\
\hline Sector of Wholesale \& Retail, and Reparation & 10.3 & 10.4 & 10.9 \\
\hline 4 & $\begin{array}{l}\text { Subsector of Wholesale \& Retail for Automobile/ Motorcycle } \\
\text { Wheels }\end{array}$ & 8.1 & 8.2 & 8.7 \\
\hline
\end{tabular}

Source : BPS data are processed.

Economic structure of Sumenep Regency is characterized by four (4) dominant sectors, such as: Sector of Agriculture, Animal Husbandry, Forestry and Fishery; Sector of Mining and Excavation; Sector of Wholesale \& Retail, and Reparation; and Sector of Construction. Mean rate of contribution from Sector of Agriculture, Animal Husbandry, Forestry and Fishery to Sumenep Regency PDRB in the last three years from 2013 to 2015 is 32.7\%. This post is the highest and next is Sector of Mining and Excavation with 37.6\%; Sector of Wholesale \& Retail, and 
Reparation with 10.5\%; and Sector of Construction with 5.9\%. Some subsectors have dominant contribution, such as: Subsector of Agriculture, Animal Husbandry, Hunting, and Farming Service with contribution of 19.6\%; Subsector of Fishery with contribution of 12.7\%; Subsector of Mining for Oil, Gas and Native Heat with contribution of 28.5\%; and Subsector of Wholesale \& Retail, and Reparation with contribution of $8.3 \%$.

In general, Sumenep Regency economic structure in the last three years from 2013 to 2015 does not indicate a great change. The most dominant sector in the economic structure of Sumenep Regency is Sector of Agriculture, Animal Husbandry, Forestry and Fishery.

Analysis on Economic Potentials:-

Economic potentials of Sumenep Regency are analyzed using parameters of Location Quotient and Klasen Typology.

\section{Location Quotient (LQ) of Sumenep Regency}

The leading sectors in Sumenep Regency are subjected to analysis with Location Quotient (LQ). The result is indicated in the following table.

Table 18:- Index of Location Quotient > 1 for Sumenep Regency from 2013 - 2015

\begin{tabular}{|l|l|l|l|l|l|}
\hline No & Economic Sector/Subsector & 2013 & 2014 & 2015 & Mean \\
\hline 1 & Sector of Mining and Excavation & 6.36 & 6.66 & 5.73 & 6.25 \\
\hline & Subsector of Mining for Oil, Gas and Native Heat & 8.59 & 9.12 & 7.63 & 8.44 \\
\hline & Subsector of Mining and Excavation for Other Materials & 1.60 & 1.57 & 1.55 & 1.57 \\
\hline & $\begin{array}{l}\text { Sector of Agriculture, Animal Husbandry, Forestry and } \\
\text { Fishery }\end{array}$ & 2.62 & 2.61 & 2.63 & 2.62 \\
\hline $\begin{array}{l}\text { Subsector of Agriculture, Animal Husbandry, Hunting and } \\
\text { Farming Service }\end{array}$ & 2.03 & 2.03 & 2.02 & 2.02 \\
\hline 3 & $\begin{array}{l}\text { Subsector of Fishery and } \\
\text { Warranty of Government Administration, Defense, and }\end{array}$ & 1.27 & 1.28 & 1.24 & 1.26 \\
\hline
\end{tabular}

Source : BPS data are processed.

Within Sumenep Regency in the last three years from 2013 to 2015, there are four (4) sectors and three (3) subsectors in the category of basis sector. Sectors with LQ more than 1 (one) involve: Sector of Mining and Excavation; Sector of Agriculture, Animal Husbandry, Forestry and Fishery; and Sector of Government Administration, Defense, and Warranty. Subsectors in basis sector category include: Subsector of Mining for Oil, Gas and Native Heat; Subsector of Subsector of Mining and Excavation for Other Materials; Subsector of Agriculture, Animal Husbandry, Hunting and Farming Service; and Subsector of Fishery.

\section{Klasen Typology Analysis}

Klasen Typology Analysis for Sumenep Regency in 2014 and 2015 is described in the following table.

Table 19:- Klasen Typology Analysis for Sumenep Regency in 2014 - 2015

\begin{tabular}{|l|l|l|}
\hline Indikator & Indicator Rate & 2015 \\
\cline { 2 - 3 } & 2014 & 1.3 \\
\hline PDRB Growth Rate for Regency/City & 6.2 & 5.2 \\
\hline PDRB Growth Rate for Province & 5.8 & 20,288 \\
\hline Income per Capita in Regency & 20,124 & 34,273 \\
\hline Income per Capita in Regency & 32,704 & Relatively Undeveloped Area \\
\hline Conclusion of Local Typology & Fast Developing Area &
\end{tabular}

Source : BPS data are processed.

In pursuance of data of the last two years from 2014 to 2015, and also by taking into account the criteria of Klasen Typology Analysis, it can be said that Sumenep Regency is relatively undeveloped area because both mean rates of economic growth and income per capita of Sumenep Regency is lower than East Java Province. Economic growth of Sumenep Regency is $6.2 \%$ in 2014 and $1.3 \%$ in 2015 while that of East Java Province is $5.8 \%$ in 2014 and $5.2 \%$ in 2015. Income per capita of Sumenep Regency attains as IDR 20,124 millions in 2014 and IDR 20,288 millions in 
2015 which all of them are lower than that of East Java Province standing at IDR 32.704 millions in 2014 and IDR 34.273 millions in 2015 .

\section{Strategy Selection Model:-}

This current research adopts model proposed by Boston Consulting Group (BCG). By this model, the selection of strategies for accelerating Sumenep Regency economic growth based on economic sectors and subsectors are described as following.

Table 20:- Strategy Selection Model Based on BCG

\begin{tabular}{|c|c|c|c|c|}
\hline No & Sector / Subsector & $\begin{array}{l}\text { Sectoral Growth } \\
(\%)\end{array}$ & $\begin{array}{l}\text { Sectoral } \\
\text { Contribution } \\
(\%)\end{array}$ & Strategy Selection \\
\hline \multirow[t]{3}{*}{1} & Sector of Mining and Excavation & 0.4 & 37.6 & Cash-Cow \\
\hline & $\begin{array}{l}\text { Subsector of Mining for Oil, Gas and Native } \\
\text { Heat }\end{array}$ & 0.0 & 28.5 & Cash-Cow \\
\hline & $\begin{array}{l}\text { Subsector of Mining and Excavation for } \\
\text { Other Materials }\end{array}$ & 2.7 & 2.4 & Moldy \\
\hline \multirow[t]{3}{*}{2} & $\begin{array}{l}\text { Sector of Agriculture, Animal Husbandry, } \\
\text { Forestry and Fishery }\end{array}$ & 3.7 & 32.7 & Star \\
\hline & $\begin{array}{l}\text { Subsector of Agriculture, Animal Husbandry, } \\
\text { Hunting and Farming Service }\end{array}$ & 2.85 & 19.6 & Cash-Cow \\
\hline & Subsector of Fishery & 5.1 & 12.7 & Star \\
\hline \multirow[t]{2}{*}{3} & $\begin{array}{l}\text { Sector of Government Administration, } \\
\text { Defense, and Warranty }\end{array}$ & 1.75 & 2.9 & Moldy \\
\hline & Mean & & & \\
\hline
\end{tabular}

In Sumenep Regency, the post of Star Sector is occupied by Sector of Agriculture, Animal Husbandry, Forestry and Fishery. The strategy implemented by this sector is by compiling huge supports of new investment fund, and this sector then becomes "improvident" in capital necessity. Although improvidence is presented, this Star Sector is the expected sector with bright future in Sumenep Regency. Only one subsector remains in star category of Sumenep Regency, and this is Subsector of Fishery.

Sector of Government Administration, Defense, and Warranty represents Moldy Sector. This sector does not have adequate capacity to produce the expected result either now or then. It is also "negligible". Moreover, it would not require large amount of new investment fund because it cannot give maximum result either in current days or future. In Sumenep Regency, only one subsector has a moldy characteristic, and this is Subsector of Mining and Excavation for Other Materials.

Furthermore, Sector of Mining and Excavation is one with cash-cow characteristic. It is surely not powerful enough to meet the future expectation. Although it is less powerful, but it represents a relatively good source of growth in Sumenep Regency. This sector would not draw large amount of new investment fund. There are two subsectors in Sumenep Regency that are included into cash-cow category, respectively Subsector of Mining for Oil, Gas and Native Heat and Subsector of Agriculture, Animal Husbandry, Hunting and Farming Service.

\section{Conclusion And Suggestion:-}

Pursuant to the results of analysis, some conclusions have been made.

1. Economic structure in Sampang Regency is dominated by four (4) main sectors, such as: Sector of Agriculture, Animal Husbandry, Forestry and Fishery; Sector of Mining and Excavation; and Sector of Wholesale \& Retail, and Reparation.

2. Bangkalan Regency economic structure is dominated by four (4) leading sectors, including: Sector of Mining and Excavation; Sector of Agriculture, Animal Husbandry, Forestry, and Fishery; Sector of Mining and Excavation; Sector of Wholesale \& Retail, and Reparation; and Sector of Construction.

3. Pamekasan Regency has its economic structure dominated by four (4) leading sectors, such as: Sector of Agriculture, Animal Husbandry, Forestry, and Fishery; Sector of Mining and Excavation; Sector of Wholesale 
\& Retail, and Reparation; Sector of Construction; and Sector of Government Administration, Defense, and Warranty.

4. Four (4) sectors have been dominant in Sumenep Regency, including: Sector of Agriculture, Animal Husbandry, Forestry, and Fishery; Sector of Mining and Excavation; Sector of Wholesale \& Retail and Reparation; and Sector of Construction.

\section{Suggestion:-}

Based on the result of regional potential mapping from Sampang, Bangkalan, Pamekasan, and Sumenep Regencies, then some recommendations for the next policy-making are given as follows.

1. Policies concerning with development and investment for agriculture sector must be improved, and it prevails to all research locations including Sampang, Bangkalan, Pamekasan, and Sumenep Regencies. Such policies would be important for regencies with leading capacity in agriculture because it may facilitate them to export their commodity products to other regions. These policies can also maintain and develop leading capacity of the regions over the others.

2. Investment into Sector of Mining and Excavation in Sampang, Bangkalan, Pamekasan, and Sumenep Regencies is considered as having good prospect. These regencies have been able to export their mining and excavation materials to other regions. To maintain and develop such capacity, then the development in this sector should be put into agenda as the main priority. Relevant policies and laws could be made to regulate excessive exploitation, to prevent the transgression of threshold and also to enforce conservation-based excavation activity.

3. More prospective investment can be done in Sector of Electricity, Gas and Drink Water. All regencies, including Sampang, Bangkalan, Pamekasan, and Sumenep Regencies, are already open for such investment. The government should take the following policies:

a. Water exploitation must be regulated by which potential limit of conservation water would be set at possible degree of exploitation to prevent water crisis. Recalling a fact that water resource in all research regencies is not renewable, and the necessity of water is irreplaceable, such water regulation would give important effect.

b. Industrial region consisting of a lot of companies often needs large quantity of water resource. Number of AMDK companies are also mushrooming. The effect of these companies can be softened through the enforcement of protection initiative for the conservation forestry and also the immediate area to preserve any water resources that are possibly managed by the region for community interest.

\section{References:-}

1. Anonim, 1999, Undang-Undang Otonomi Daerah 1999, Penerbit Kuraiko Pratama, Bandung.

a. 2013, Statistik Keuangan Pemerintah Daerah Kabupaten/Kota di Indonesia, Badan Pusat Statistik Daerah Tingkat I Jawa Timur,Surabaya.

b. 2014, Statistik Keuangan Pemerintah Daerah Kabupaten/Kota di Indonesia, Badan Pusat Statistik Daerah Tingkat I Jawa Timur, Surabaya.

2. Basri, 1995, Perekonomian Indonesia Menjelang Abad XXI (Distorsing, Peluang dan Kendala), Penerbit Erlangga, Jakarta.

3. Dasril, Henry \& Hessel, 2004, Kebijakan \& Manajemen Keuangan Daerah, Penerbit YPAPI, Yogyakarta.

4. Elmi, Bchrul, 2002, Keuangan Pemerintah Daerah Otonom di Indonesia. Penerbit Universitas Indonesia (UI Press), Jakarta.

5. Ibnu Syamsi, 1993, Dasar-Dasar Kebijaksanaan Keuangan Negara, cetakan kedua, Penerbit PT.Bina Aksara, Jakarta.

6. Khusaini, 2006, Ekonomi Publik, Desentralisasi Fiskal dan Pembangunan Daerah, Penerbit BPFE UNIBRAW, Malang.

7. Kuncoro, Mudrajad, 2004, Otonomi \& Pembangunan Daerah Reformasi, Perencanaan, Strategi, dan Peluang, Jakarta : Penerbit Erlangga.

8. Mahmudi, 2010, Manajemen Keuangan Daerah, Penerbit Erlangga, Jakarta.

9. Permendagri, No 27 Tahun 2014 tentang Pedoman Penyusunan, Pengendalian dan Evaluasi Rencana Kerja Pembangunan Daerah Tahun 2015.

10. Permendagri, No 54 Tahun 2010 Tentang Pelaksanaan PP No. 8 Tahun 2008 tentang Tahapan, Tatacara Penyusunan, Pengendalian, dan Evaluasi Pelaksanaan Rencana Pembangunan Daerah.

11. Saragih, Panglima, 2003, Desentralisasi Fiskal dan Keuangan Daerah Dalam Otonomi, Jakarta; Penerbit Ghalia Indonesia. 
12. Stat. Daniel dan Inge Hovlan, 2012, http://Subliyanto, Wordpress, com /2012/12/13 /analisis-swot/.

13. Syafrizal, 1997. Pertumbuhan Ekonomi dan Ketimpangan Regional Wilayah Wilayah Indonesia Bagian Barat. Prisma LP3ES, 3,27-38.

14. Syafrizal, 2008. Ekonomi Regional: Teori dan Aplikasi. Baduose Media.

15. Tarigan, Robinson. 2005. Perencanaan Pembangunan Wilayah. Jakarta: Bumi Aksara.

16. Todaro, Michael. 2000. Pembangunan Ekonomi. Jakarta. Bumi Aksara. 